\title{
Promoting professionalism in RN-BSN education
}

\author{
Debra L. Wagner \\ School of Nursing, University of North Florida, United States \\ Correspondence: Debra L. Wagner. Address: University of North Florida, School of Nursing, 1 UNF Drive, Jacksonville, FL \\ 32224, USA. Telephone: 904-620-1478. Email: dwagner@unf.edu.
}

Received: July 28, 2012

Accepted: September 5, 2012 Online Published: December 7, 2012

DOI : 10.5430/jnep.v3n5p9

URL: http://dx.doi.org/10.5430/jnep.v3n5p9

\section{Abstract}

Professional nursing practice entails more than the employment of technical skills while caring for patients. It also includes participation in professional organizations and involvement in the community. While there is evidence of the need for RN-BSN programs to provide learning activities that will promote sustained professionalism in the baccalaureate nurse, there is a paucity of literature describing such activities. This article describes the case report of one university's use of curricular changes in the RN-BSN program through inclusion of clinical activities to enhance professional development and values. The responses of RN-BSN students to these clinical experiences demonstrate engagement and interest in both professional nursing organization and civic meetings, as well as personal satisfaction as a result of their involvement in these experiences. Nursing faculty teaching in RN-BSN programs should find these comments inspiring, and be motivated to incorporate some of these clinical activities into their curriculum to promote sustained professionalism in RN-BSN students after graduation.

\section{key words}

RN-BSN education, Nursing professionalism, Clinical experiences

\section{I ntroduction}

The Health Resources and Services Administration of the U. S. Department of Health and Human Services reported that as of 2008, the largest number (45.4\%) of registered nurses in the United States completed their initial nursing education through an Associate Degree in Nursing (ADN) program while an additional 20.4\% attended a diploma program ${ }^{[1]}$. Traditionally, the focus of diploma and associate degree nursing programs has been technical skills, and preparing students to care for patients at the bedside. However, in today's healthcare environment, nurses are now facing ever increasing complexities in patient care. The landmark study by Aiken, Clark, Cheung, Sloan and Silber ${ }^{[2]}$ demonstrated lower mortality and improved outcomes in surgical patients cared for by registered nurses (RNs) educated at the Bachelor of Science in Nursing (BSN) level or higher. These important findings support the argument for increasing the educational preparation of nurses to the baccalaureate level.

The American Association of Colleges of Nursing (AACN) asserted its position that the BSN degree is the minimum education preparation for entry into professional nursing practice ${ }^{[3]}$. Not only does BSN education prepare nurses for a variety of patient settings and increased critical thinking skills, it also includes additional studies in liberal arts, by incorporating cultural diversity, leadership and management, and the development of nursing professionalism ${ }^{[4]}$. Since 
many RNs in the United States pursue additional education in a Registered Nurse to Bachelor of Science in Nursing (RN-BSN) program, it is incumbent upon universities that offer these programs to provide a curriculum that enhances the professional preparation of these RNs. One of the goals of RN-BSN programs should be to socialize RNs from the role of technical nurse to that of the professional nurse by including clinical experiences to enhance professional development and values. This paper will provide a case study presentation of the way one university made changes to the curriculum in order to enhance the clinical experiences extended to RN-BSN students in their capstone course, with the potential to motivate nurses to participate in professional organizations and civic entities in order to advocate for their profession and their community. Student comments reflecting on their experiences will also be shared.

\section{Background}

Hall ${ }^{[5]}$ described professionalism as a process, and stated professional attitudes are formulated through socialization during the educational process and in the workplace. Participation in professional organizations has been identified as one of the attributes of professionalism, and reflects a commitment to the profession. Hwang, Lou, Han, Cao, Kim and $\mathrm{Li}^{[6]}$ found a positive correlation between levels of education and levels of professionalism. Nurses with higher education demonstrated higher levels of professionalism.

Support for professional organizations includes membership in the organization and actively attending meetings. Wynd's study demonstrated nurses who joined professional organizations possessed a higher perception of professionalism than those who were not members ${ }^{[7]}$. Advocating for professional organization membership should begin while students are still in school, so that they can begin the process of socialization to professionalism.

Providing a learner centered educational experience that will enhance sustained professionalism among RN-BSN students can be challenging. Kubsch, Hansen, \& Huyer-Eatwell ${ }^{[8]}$ found RN-BSN students who were currently enrolled in a baccalaureate completion program demonstrated a higher mean score on perceived professionalism than other groups of RNs, regardless of their educational preparation. Upon graduation, however, the mean scores for perceived professionalism dropped. It was suggested that the curriculum used may not have been adequate to instill the continued practice of professionalism. Thus, Morris \& Faulk ${ }^{[9]}$ called for nurse educators to document learning activities adopted into RN-BSN curriculum with the potential to foster the development of professionalism in RN students.

\section{Curricular changes}

The RN-BSN program at a state university in Florida institutes a curriculum that completes the coursework RNs would have taken had they attended the BSN prelicensure program at this university. The RN-BSN students are given credit for the courses they completed in their diploma/ADN programs, which include the technical/skilled areas of nursing, without repeating prior courses or clinical experiences. Previous to making changes to the curriculum, RN-BSN students were integrated with prelicensure students while taking the courses they needed to complete their baccalaureate degree. Since the literature showed RN-BSN students had a better educational experience when they are in a cohort with fellow RNs ${ }^{[10]}$, a separate cohort for RN-BSN students was implemented. This RN-BSN program expands the students' knowledge of professional nursing and completes their BSN education without being redundant.

In the capstone course within the curriculum, which includes didactic and clinical requirements, all BSN students begin the process of transitioning from the baccalaureate student role to the role of a professional baccalaureate prepared nurse, after completing courses in socialization to professional nursing, nursing research, leadership and management, applied nursing ethics, chronic illness management, family/community assessment and community health. The focus of this capstone course is on skills used by the nurse to excel as a clinician, professional leader, communicator, and as a citizen. In the clinical component of this course, the prelicensure students are required to precept with a BSN prepared RN in the acute care setting, in order to integrate all the skills learned to date, and prepare for a future job as a registered nurse. Since the RN-BSN students participated in this type of clinical experience in their prelicensure program, the challenge was to 
create a clinical experience that would be unique to the RNs, of interest to them, and create a sense of professionalism in nursing as they assumed the role of professional leader and citizen.

Senior faculty members met to discuss ways the curriculum could be modified to assist the RN-BSN students in synthesizing the core value of professionalism into their nursing practice through clinical experiences in the RN-BSN program. Using the AACN Essentials of Baccalaureate Education, faculty decided on clinical experiences that would help the RN-BSN student meet Essential V: Healthcare Policy, Finance, and Regulatory Environments, whereby students would be able to examine state regulations for the practice of nursing and explore legislative processes and the impact on health care and other policy arenas; and Essential VIII: Professionalism and Professional Values, through demonstration of the pursuit of engagement in the profession to promote professional growth ${ }^{[3]}$. Essentials I, II, III, IV, VI, VII, and VIII were identified as met in other areas throughout the curriculum. It was decided the RNs could choose from a list of clinical opportunities that included professional nursing organization and civic meetings, Board of Nursing meetings, and nursing conferences, giving the students a lot of flexibility. They could select the experiences they were most interested in, and worked with their job and home life schedule. After participating in a clinical experience, to account for their clinical hours, the RNs would submit journal entries discussing the event attended, information learned, and feelings about the experience.

As students participated in the clinical experiences required when this new curriculum was instituted, faculty teaching this capstone course read the journal entries the RN-BSN students submitted. Faculty made comments and inquiries, to elicit more information when needed and validate the feelings students documented in response to the journal entries. Since this was a new clinical requirement, unique in the RN-BSN curriculum, faculty discovered that students were now exemplifying characteristics of professionalism that had not been realized with previous clinical requirements.

\section{Clinical experiences}

\section{Professional nursing organization meetings}

The RN-BSN students were given a list of clinical opportunities for them to choose from on the first day of class in their capstone course. One of the options was to attend the Florida Nurses' Association (FNA) Membership Assembly, which was being held at a conference center approximately a five hour drive from the university. Faculty learned most of the students in the class had never attended a professional nursing conference before. Since many hospitals typically don't pay for individual nurses to attend professional conferences, the RNs admitted they hadn't considered going to one, and weren't sure they were willing to pay to attend one either. In fact, one commented that she hadn't attended a conference previously because she felt they would be dull and monotonous. The FNA was contacted, and they agreed to waive the registration fee for RN-BSN students attending the annual convention for the first day. The Director of the School of Nursing at our university was approached about subsidizing the attendance of nurses attending this FNA meeting and she immediately responded with providing scholarships for hotel fees for those attending the conference. The waived registration fee and paid hotel rooms resulted in two-thirds of the students enrolled in the capstone course attending this FNA Membership Assembly, since they could carpool to share gasoline expenses and afford to purchase their own meals.

The responses from the RN-BSN students after attending the conference were overwhelmingly positive. One student said "I felt very professional just being there." Another said "I am thankful for this experience. It makes you realize how big the nursing field really is and how we all must work together to create change in nursing." Still another said "it inspired me to want to join FNA and become proactive", while another admitted that although she was a member of FNA she planned to renew her membership, and become involved with the local chapter.

Many RNs went to local professional nursing organization meetings, such as the Emergency Nurses Association and Oncology Nurses Society, and were surprised to learn the extent of the issues introduced at these meetings. They witnessed 
discussions about scope of practice, evidenced-based practice, legislative regulation, workforce research and membership development, which were some of the concepts they learned in their coursework in the RN-BSN program. Some recognized nurse managers and previous and current nursing faculty at these meetings, which fostered collegiality and were pleased that their attendance at these meetings was noticed and they were welcomed.

\section{Legislative/ Civic meetings}

Another clinical opportunity made available to the students was to attend the FNA Lobby Days in the state capital. Even though the RNs attending this event paid for this experience themselves, they learned a lot about the political processes in Florida and had the opportunity to personally meet with their state representative or senator, or their legislative aides, and discuss nursing issues identified by the FNA lobbyist in the morning general session. The students' comments included: "I thought it was a worthwhile event ... I learned about lobbying and how it is relevant to the nursing profession and the communities we serve"; "This was a wonderful student experience, which allowed us to understand the influence that nurses can have on changing legislation"; "Lobby Day in Tallahassee was such a great experience! I have never participated in anything like this (before) so it was neat to see the "lobbying” and political side of nursing"; "FNA Lobby Days was a new experience for me. I had never lobbied for anything before, but going to this conference opened my eyes to ways we can have our voice heard in our government. I learned a great deal about our government and had fun advocating for my fellow nurses.”

Students were encouraged to attend local civic events, to become aware of the political issues and processes that had the potential to affect the healthcare of the community. Many students attended city council meetings. For most of them, this was their first time to attend, and they described the experience as interesting, eye-opening, and exciting, as they were exposed to discussion of issues relevant to the homeless shelters in the city, troubled youth mentoring programs, crime, and safety for school children and teachers. As one stated, "Our community has a place for voices to be heard, no matter how opinionated those voices may be. I really enjoyed this opportunity because it makes you aware of current proposals and situations relevant to this community.”

A unique opportunity was afforded one group of RNs in the form of a mayoral candidate dinner. Four citizens running for mayor were present, and the students got an opportunity to interview each of the candidates personally. Becoming aware of issues that confronted the local community was advantageous as one student remarked, "going to the City Council meeting helped in forming the questions that I asked each candidate.” One of the candidates really caught the attention of the students - she was a RN! It was a new awareness of one way a nurse could get involved in the political process and they were impressed with the RN candidate's political experience of representing nurses in the union throughout Florida and supporting bills in Washington, D. C.

\section{Board of nursing meetings}

The students were encouraged to attend one of the Florida Board of Nursing (BON) meetings. Although some of the students had previously attended a BON meeting while in their prelicensure nursing program, now that they were licensed, the meetings held a new meaning and importance to them. The RNs expressed surprise at the extent of the unprofessional actions committed by fellow nurses, which led to a suspension/revocation of their license. Many commented on gaining a new respect for following the law, a renewed realization of the duty to protect their patients, and appreciation of their licenses. Some identified feelings of inspiration, after witnessing "real people" who overcame addictions trying to make amends to society. One student relayed the best part of this experience was learning about the inner workings of the Board of Nursing and seeing there are many nonclinical opportunities for nurses to make a difference in state. Another student stated that attending these meetings improved her nursing skills by causing her to become more diligent in checking physician orders, performing more in-depth physical assessments, and asking for help when in doubt about something. 


\section{Discussion}

Providing the RNs with the opportunity to attend and become involved in professional nursing and civic meetings gave them the incentive to participate in activities not experienced to date, and gave them a renewed sense of identity with the profession of nursing. Students reported being "refreshed" and "a sense of camaraderie with other nurses" after attending conferences. Others expressed interest in becoming involved with local chapters of professional nursing organizations.

Not only did these clinical experiences give students personal satisfaction, fulfillment, and a sense of professionalism, an unexpected benefit was a new appreciation for their supervisors. After attending the Board of Nursing meeting, one student wrote "I now view my nurse manager with more respect because she watches out for me and the other nurses I practice with. She attempts to ensure that we practice correctly, and I now more fully understand why she does what she does, to protect us from the long term consequences of our actions."

Encouraging attendance and involvement in professional nursing activities and civic meetings in fulfillment of clinical requirements is certainly one way RN-BSN student can start on the path to the practice of professional nursing. One RN wrote, "You are taught about 'FNA' and 'ANA' in nursing school and you hear about it at work, but the concept behind it is not truly appreciated until you attend such a meeting." It would behoove RN-BSN nursing programs to consider adding clinical experiences that would engage the students in activities both within the profession and the community, as it provides an opportunity to promote sustained professionalism within the baccalaureate nurse. Students should not only realize their transition from technical to professional nurse throughout the RN-BSN curriculum, but faculty need to encourage these nurses to engage in the furtherance of the profession, as they internalize professional values in a sustainable way through their clinical experiences, in order to become nursing leaders of the future.

\section{References}

[1] U.S. Department of Health and Human Services/Health Resources and Services Administration. 2010. The Registered Nurse Population: Initial Findings from the 2008 National Sample Survey of Registered Nurses. Available from: www.bhpr.hrsa.gov/healthworkforce/rnsurveys/rnsurveyinitial2008.pdf.

[2] Aiken LH, Clarke SP, Cheung RB, Sloan DM, Silber JR. Educational levels of hospital nurses and surgical patient mortality. JAMA. 2003; 290: 1617-1623. http://dx.doi.org/10.1001/jama.290.12.1617

[3] American Association of Colleges of Nursing. 2008. The Essentials of Baccalaureate Education for Professional Nursing Practice. Washington, DC: Author. Available from: http://www.aacn.nche.edu/publications/order-form/baccalaureate-essentials.

[4] Clark CL. The professional socialization of graduating students in generic and two-plus-two baccalaureate completion nursing programs. Journal of Nursing Education. 2004; 43: 346-351. PMid:15344370

[5] Hall RH. Professionalization and bureaucratization. American Sociological Review. 1968; 63: 92-104. http://dx.doi.org/10.2307/2092242

[6] Hwang JI, Lou F, Han SS, Cao F, Kim WO, Li P. Professionalism: the major factor influencing job satisfaction among Korean and Chinese nurses. International Nursing Review. 2009; 56(3): 313-8. PMid:19702804 http://dx.doi.org/10.1111/j.1466-7657.2009.00710.x

[7] Wynd A. Current factors contributing to professionalism in nursing. Journal of Professional Nursing. 2003; 19(5): 251-261. PMid: 14613064. http://dx.doi.org/10.1016/S8755-7223(03)00104-2

[8] Kubsch S, Hansen G, Huyser-Eatwell V. Professional values: the case for RN-BSN completion education. The Journal of Continuing Education in Nursing. 2008; 39(8): 375-384. PMid:18714613

[9] Morris AH, Faulk, D. Perspective transformation: enhancing the development of professionalism in RN-to-BSN students. Journal of Nursing Education. 2007; 46(10): 445-452. PMid:17955741

[10] Delaney C, Piscopo, B. There really is a difference: nurses experiences with transitioning from RNs to BSNs. Journal of Professional Nursing. 2007; 23(3): 167-173. http://dx.doi.org/10.1016/j.profnurs.2007.01.011 